\title{
Article \\ Discrete Seed Feeder Designing for Mobile Apparatus: Early Results for Pinus sylvestris L. Species
}

\author{
Ivan V. Bacherikov ${ }^{1}\left[\right.$, Arthur I. Novikov ${ }^{2, *}$ and Evgeniy P. Petrishchev ${ }^{2}$ \\ 1 Department of Technological Processes and Machines of Forest Complex, Saint Petersburg State Forest \\ Technical University Named after S.M. Kirov, 5, Institutskiy per., 194021 St. Petersburg, Russia; \\ ivashka512@gmail.com \\ 2 Mechanical Department, Voronezh State University of Forestry and Technologies Named after G.F. Morozov, \\ 8, Timiryazeva, 394087 Voronezh, Russia; petrishchev.vgltu@mail.ru \\ * Correspondence: arthur.novikov@vglta.vrn.ru
}

Citation: Bacherikov, I.V.; Novikov, A.I.; Petrishchev, E.P. Discrete Seed Feeder Designing for Mobile Apparatus: Early Results for Pinus sylvestris L. Species. Inventions 2021, 6 14. https://doi.org/10.3390/ inventions6010014

Academic Editor: Konstantinos

G. Arvanitis

Received: 30 December 2020

Accepted: 29 January 2021

Published: 31 January 2021

Publisher's Note: MDPI stays neutral with regard to jurisdictional claims in published maps and institutional affiliations.

Copyright: (C) 2021 by the authors Licensee MDPI, Basel, Switzerland. This article is an open access article distributed under the terms and conditions of the Creative Commons Attribution (CC BY) license (https:// creativecommons.org/licenses/by/ $4.0 /)$.

\begin{abstract}
Discrete feeding of forest seeds is an urgent task for accurate detection of seeds during grading and reducing the seeding rate. The study used Pinus sylvestris L. seeds from cones collected in a natural stand of the Lisinsky educational-and-experimental forestry farm, Leningrad region, Russia, in 2017. Well-known methods for determining the properties of bulk materials were used; the results were processed by mathematical statistics using the MS Excel program. The physical and mechanical properties of uncalibrated seeds as a bulk material were determined. The angle of repose of Pinus sylvestris L. seeds, determined using a hollow cylinder by calculation, is $24.92^{\circ}$. The angle of repose of Pinus sylvestris L. seeds, determined using a hollow cylinder and a goniometer, is $32.7^{\circ}$ The significant discrepancy $\left(\sim 8^{\circ}\right)$ in the values obtained by these methods is explained by the seeds shape. The flowability of Pinus sylvestris L. seeds corresponds to an excellent (free) category. The study will enable correct seed treatment protocols for sustainable forest management. However, some questions remained unresolved: how to orient a single seed in the right direction? How does seed-size calibration affect the angle of repose?
\end{abstract}

Keywords: discrete seed feeding; small-size forest seeds; Pinus sylvestris L.; physical-and-mechanical properties; seeds angle of repose; mobile UAV-based seeder; mobile optoelectronic grader; forest landscape restoration

\section{Introduction}

The implementation of global forest landscape restoration initiatives [1] requires a huge amount of forest reproductive material. Regardless of whether planting seedlings [2] or seeding seeds [3,4] is the creation of forest crops, all of these purposes require a significant amount of high-quality seeds. The quality of seeds means, first of all, their germination and viability. For non-invasive determination of seed viability in stationary laboratory conditions, various advanced biophysical techniques can be used: spectrometric [5], nuclear magnetic resonance [6], and many others. However, in them, the sample is fixed in the cuvette manually, which does not allow the use of these methods in production field conditions. To perform seed sorting in the field, it is advisable to use spectrometric methods that use the Near InfraRed (NIR) and VISible (VIS) wavelength ranges of detecting radiation [7-12]. To ensure high-quality grading of seeds of scots pine [10,11] or acorns of oak petiolate [8], according to the spectrometric properties, a discrete seed supply to the diagnostic systems of separators based on new optoelectronic systems [12], and theoretical justification of the geometric and energy parameters of optical radiation [7] is necessary. In turn, the separation of seeds in the VIS range gives some differences in the growth of seedlings [9], and in the NIR range, an increase in ground germination in an automated nursery. These methods have the highest potential for the cost-quality ratio and do not 
have a severe impact on the seed, unlike methods using X-rays or ultraviolet light. VISNIR techniques are implemented in the designs of mobile optoelectronic sorters [13-15], developed with the participation of one of the authors. The grader consists of several technological parts, including feeding, diagnostic, and grading modules. «The seeds are delivered from the dosing module to the vertical transparent pipeline at a frequency set by the microprocessor [16]». Without any doubt, the initial and slowest module was, and remains, the orienting (feeding) module. When striving for the ideal option, this module should provide the following:

- Simplicity of design;

- $\quad$ Storage of seed stock for the implementation of the technological cycle;

- Feeding seeds into the seed duct one at a time;

- $\quad$ Set and adjustable seed feeding frequency;

- A given orientation of the seeds in space or a clear detection of the initial position of the seed before entering the seed duct;

- $\quad$ Easy to pair with other modules.

The seeds obtained with the help of a mobile optoelectronic grader can be sown in several ways. The first option involves precise seeding in closed ground (containers) using a stationary automated gravity precision seeder (BCC, Landskrona, Sweden). The second option involves sowing seeds in the open ground using ground-based seeders, which are combined with a tractor. The design of ground-based seeders includes seeding devices of different types both according to the method of seed feeding [17] and the method of adaptive regulation of the seeding rate [18]. If it is impossible to implement the first and second options due to the climatic and geomorphic features of the sown areas, it is advisable to use a useful target load for adaptive aerial seeding [19] on the basis of micro Unmanned Aerial Vehicles (micro-UAVs) [20].

There may be a contradiction that needs to be resolved individually for each specific reforestation process. On the one hand, all precision seeding devices require mandatory sizing of the seeds. On the other hand, at the genetic level, sizing seeds by size can discard entire families [21].

To develop mobile devices for both optical sorting and seeding, it is necessary to understand how seeds will behave in seed water, be able to determine their exact orientation in space and ensure free flow without the formation of arches and traffic jams. The aim of the study is to develop a design and technological scheme for the discrete supply of scots pine seeds. The device should have small dimensions, a simple design and provide a pieceby-piece supply of seeds to mobile devices: an optoelectronic grader or a seeding apparatus based on micro-UAVs. This article will answer the following questions. Is it possible to free hydraulic flow of pine seeds from the hopper? What physical and mechanical properties of seeds have the greatest impact on their expiration without arching? What is the effective size of the mini-hopper opening for feeding seeds?

\section{Materials and Methods}

\subsection{Seed Samples}

In this study, the seeds of Pinus sylvestris L. species (hereinafter referred to as seeds) were used. Seeds were obtained using standard technology [22] from cones collected in 2017 in the natural stand of Lisinsky educational-and-experimental forestry farm (Leningrad region, Lisino-Korpus, Russia). The seeds were extracted from the cones, dewinged, dried to a moisture content of $8 \%$, and prepared on a gravity separator [9]. Seeds were not size-calibrated, and seed sizes were determined using the micrometer MK25-2 (Kalibr Moscow Tool Factory, Moscow, Russia). The seed shape is an ellipsoid that is asymmetrical along three axes [23] (see Figure 1a,b). 


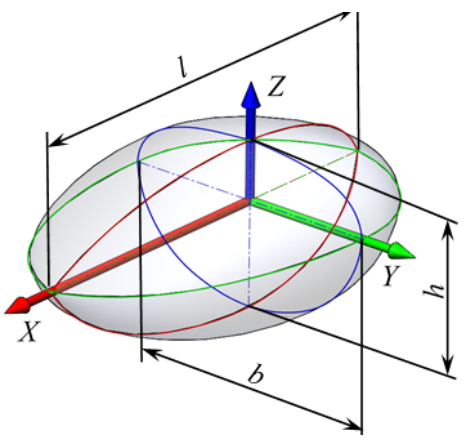

(a)

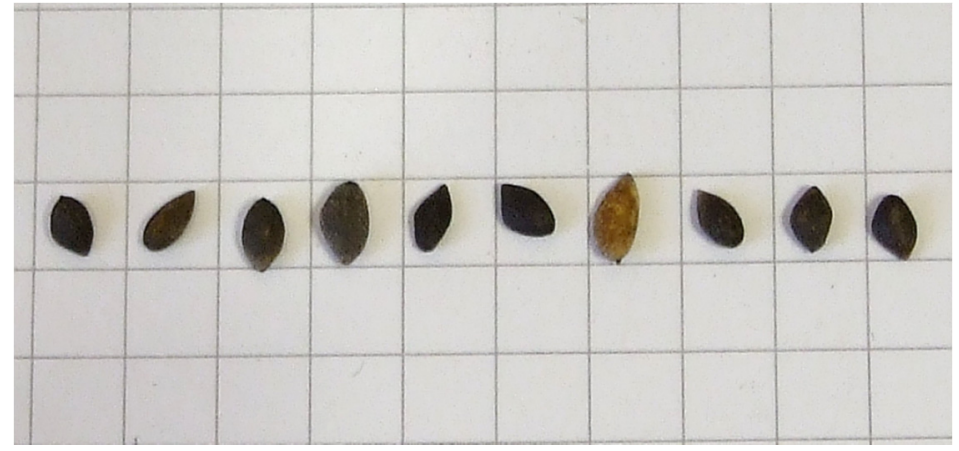

(b)

Figure 1. Pinus sylvestris L. seed shape used in study: (a) schematic [23]; (b) photo by authors. The size of one cell is $5 \times 5 \mathrm{~mm}$.

\subsection{Pilot Experiments}

For preliminary experiments to determine the behavior of pine seeds as a loose material, a cone and three cylinders with a height of $210 \mathrm{~mm}$ and a diameter of 10, 20, $30 \mathrm{~mm}$ were made of paper to determine the angle of natural slope. At the first stage of the preliminary experiment, the main task was to determine the required diameter of the outlet. By dropping the seeds one by one, it was possible to establish a tendency to get stuck in the outlet with a diameter of $5 \mathrm{~mm}$ due to the reversal of the seed. When filling the entire array of seeds into the cone, seeds-arch forming was observed, and the paused seeds tightly clogged the outlet feeder and required manual removal. When cutting the outlet feeder and, accordingly, increasing the diameter of the outlet hole to $6 \mathrm{~mm}$, a tendency to free flow of two or more seeds at the same time was revealed. Based on the above, we can conclude about the required diameter of the outlet: $5.1 \mathrm{~mm} \leq \mathrm{d}_{\text {out }} \leq 5.9 \mathrm{~mm}$.

At the second stage of the preliminary experiment, it was necessary to characterize the seeds flowability and establish the possibility of seeds-wall forming. Moreover, 30 trials with 10, 20, $30 \mathrm{~mm}$ cylinders were performed. The character of seed flow in the absolute majority of experiments is hydraulic, without pause and seeds-wall forming. For a $10 \mathrm{~mm}$ diameter cylinder, a single case of seeds-arch forming, which collapsed from an external impact on the cylinder wall, was recorded (see Data Set).

Determination of the seeds static angle of repose was carried out according to the methods described in $[24,25]$ using a hollow cylinder, ruler and goniometer. First, we determined the angle of the natural slope calculated value $\alpha_{0 \text { calculated }}$, measure the height of the formed of seeds heap and the diameter in three directions through $120^{\circ}$ and substituting these values into the equation

$$
\alpha_{0 \text { calculated }}=\operatorname{arctg}\left(\frac{2 H_{\text {heap }}}{D_{\text {heap }}}\right) \text {, }
$$

where $H_{\text {heap }}$ is the height of seeds heap, $\mathrm{mm} ; D_{\text {heap }}$ is the diameter of seeds heap, $\mathrm{mm}$.

Second, the measured value of the angle of the natural slope was determined, the height of the formed seeds heap and the diameter in three directions through $120^{\circ}$ are measured.

From the papers [26,27], a simple formula is known for determining the size of the hopper outlet, based on the use of the equivalent diameter [28] of the particle:

$$
r=4 \cdot \sqrt{l \cdot b}
$$

where $r$ is the radius of the outlet, $\mathrm{mm} ; l$ is the particle length of the bulk material, $\mathrm{mm} ; b$ is the width of the particle of the bulk material, $\mathrm{mm}$.

The seed sample was mixed for 5 min, quartered three times, then 30 seeds were selected and the length $l$ and width $b$ of the seeds were measured using a micrometer. 
Well-known methods for determining the properties of bulk materials were used; the results were processed by mathematical statistics using the MS Excel program.

\section{Results}

\subsection{Scots Pine Seeds Static Angle of Natural Slope}

The results of the experiments were summarized in Table 1.

Table 1. Results of experiments to determine the angle of natural slope for seed samples used in study $(\mathrm{N}=100)$.

\begin{tabular}{|c|c|c|c|c|c|c|c|c|c|c|c|}
\hline \multirow[t]{2}{*}{ Trial Number } & \multirow{2}{*}{$\begin{array}{c}\text { Seed Heap } \\
\text { Height } \\
H, \mathrm{~mm}\end{array}$} & \multicolumn{4}{|c|}{$\begin{array}{c}\text { Seeds Heap Diameter } \\
d_{\text {heap }}, \mathrm{mm}\end{array}$} & \multirow{2}{*}{$\begin{array}{l}\text { Angle of Natural } \\
\text { Slope, Calcu- } \\
\text { lated } \alpha_{0} \text { calculated }\end{array}$} & \multicolumn{4}{|c|}{$\begin{array}{l}\text { Angle of Natural Slope, } \\
\text { Measured } \alpha_{0 \text { measured }}\end{array}$} & \multirow{2}{*}{$\Delta\left(\alpha_{0 \text { calculated }}-\alpha_{0 \text { measured }}\right)$} \\
\hline & & 1 & 2 & 3 & Average & & 1 & 2 & 3 & Average & \\
\hline Average & 18.6 & 79.6 & 79.6 & 78.4 & 79.2 & 25.1 & 32.3 & 33.3 & 32.5 & 32.7 & -7.6 \\
\hline Mode & 18 & 79 & 78 & 78 & 79.33 & 24.41 & 31 & 34 & 34 & 33.67 & -8.43 \\
\hline Min & 14 & 73 & 73 & 72 & 76.00 & 19.00 & 28 & 24 & 27 & 27.00 & -13.12 \\
\hline Max & 25 & 89 & 85 & 86 & 85.33 & 32.22 & 38.5 & 39 & 39 & 37.17 & -0.78 \\
\hline Median & 18 & 79 & 80 & 78 & 79.33 & 24.92 & 32 & 33.75 & 32.5 & 32.75 & -7.97 \\
\hline Variance $\sigma^{2}$ & 3.60 & 6.21 & 6.32 & 8.24 & 3.48 & 5.36 & 4.69 & 7.34 & 4.45 & 3.19 & 6.54 \\
\hline $\begin{array}{c}\text { Standard } \\
\text { deviation } \sigma\end{array}$ & 1.90 & 2.49 & 2.51 & 2.87 & 1.87 & 2.32 & 2.17 & 2.71 & 2.11 & 1.79 & 2.56 \\
\hline $\begin{array}{l}\text { Measurement } \\
\text { error by } \\
\text { Kornfeld } \\
\text { method }\end{array}$ & 5.50 & 8.00 & 6.00 & 7.00 & 4.67 & 6.61 & 5.25 & 7.50 & 6.00 & 5.08 & 6.17 \\
\hline
\end{tabular}

Scots pine seeds can have an angle of repose ranging from 28 to $40^{\circ}$, and humidity is a significant factor affecting the natural slope angle [29]. Similar information on the seeds of Pinus sibirica Du Tour is given in paper [30].

\subsection{Model of the Feeder and Vibration Experiments}

According to the scientific review by Lukynenko [31], the seed size of Scots pine varies and is $3-5 \mathrm{~mm}$ in length, $1.4-3.3 \mathrm{~mm}$ in width, and $1.0-2.2 \mathrm{~mm}$ in thickness. The results were entered in Table 2.

Table 2. Results of examination of seeds dimensions $(\mathrm{N}=30)$. The dash in place of the mode value of the $r$-parameter is explained by the absence of duplicate values.

\begin{tabular}{cccc}
\hline Trial Number & Seed Length $\mathbf{l , ~} \mathbf{m m}$ & Seed Width $\boldsymbol{b}, \mathbf{m m}$ & Calculated Radius of the Outlet $\boldsymbol{r}$, mm \\
\hline Average & 4.2 & 1.4 & 9.7 \\
Mode & 4.27 & 1.54 & -7.02 \\
Min & 3.19 & 1.08 & 11.62 \\
Max & 5.03 & 1.81 & 9.70 \\
Median & 4.18 & 1.41 & 0.73 \\
Variance $\sigma^{2}$ & 0.18 & 0.03 & 0.85 \\
Standard deviation $\sigma$ & 0.43 & 0.17 & 1.80 \\
Measurement error by Kornfeld method & 0.92 & 0.37 & \\
\hline
\end{tabular}

Thus, based on the results in Tables 2 and 3, and guided by Equations (1) and (2), the size of the exhaust feeder should be assumed to be at least $5.5 \mathrm{~mm}$. However, taking into account the purpose of the work-piece seeding, i.e., only one seed should pass through the aperture of the outlet feeder per unit of time, the diameter of the outlet hole should be $5 \mathrm{~mm}$.

Table 3. Vibromotors parameters.

\begin{tabular}{cccc}
\hline Vibromotor Brand & Vibromotor Type & Revolutions Per Minute, $\left(\mathbf{r}\right.$ min $^{-\mathbf{1}}$ ) Hz & Voltage, V \\
\hline MTR-VIBRATING & coin (shaftless) motor & $(10,000) 166.67 \mathrm{~Hz}$ & 3 \\
QX-6A-3V & brushless with nozzle & $(9000) 150 \mathrm{~Hz}$ & 3 \\
\hline
\end{tabular}


A paper feeder was made with the following dimensions: $60 \times 60 \mathrm{~mm}$ in the upper part, $5 \times 5 \mathrm{~mm}$-the size of the outlet, the angle of inclination of the walls- $40^{\circ}$ (Figure 2). The upper part of the feeder was reinforced with stiffeners, vibration motors were placed manually to the wall of the feeder (Figure 3, Table 3).

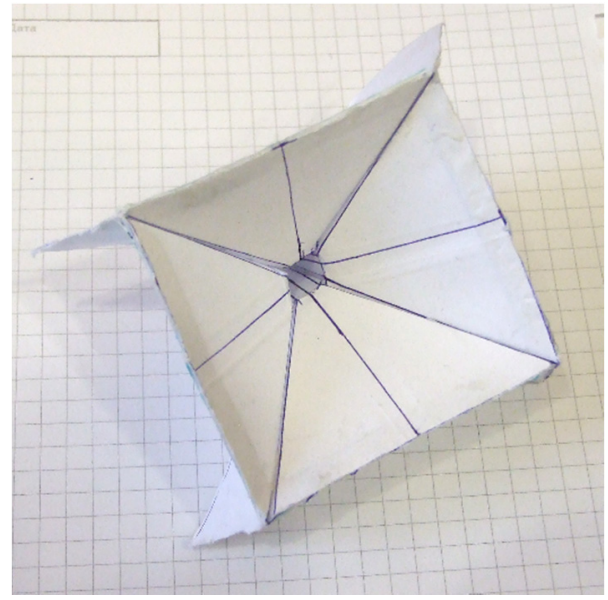

(a)

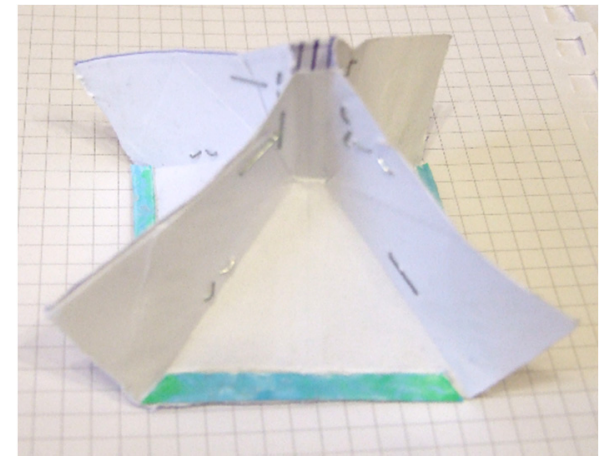

(b)

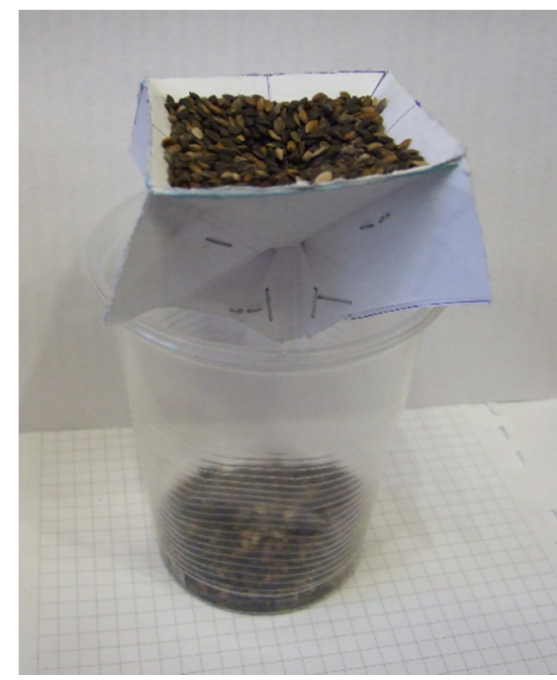

(c)

Figure 2. Feeder model: (a) front view; (b) bottom view; (c) feeder with seeds.

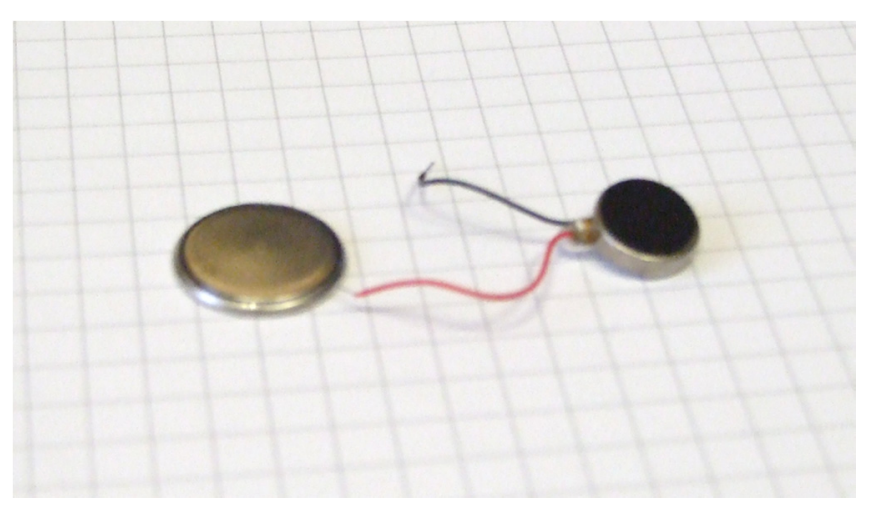

(a)

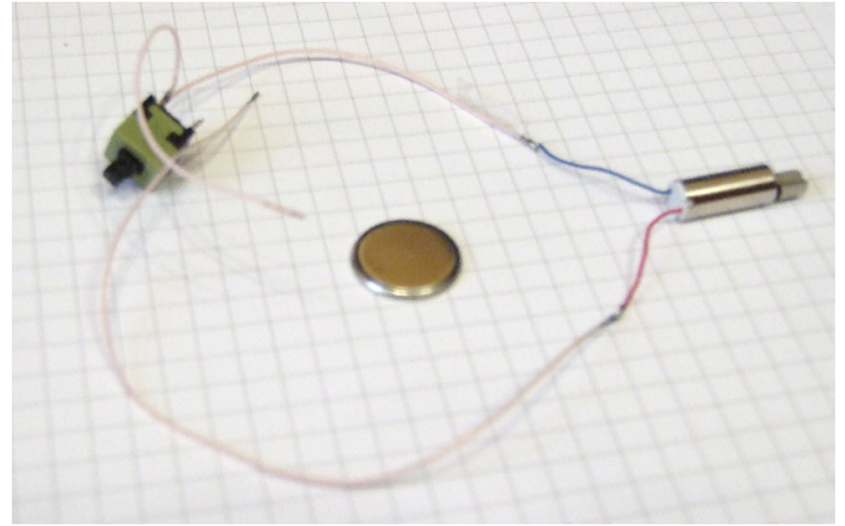

(b)

Figure 3. Vibromotors used in this study: (a) coin motor MTR-VIBRATING; (b) vibromotor QX-6A-3V.

The angle of repose of the Pinus sylvestris L. Seeds used in this study, determined using a hollow cylinder by the even method, is $24.92^{\circ}$. The angle of natural slope of Pinus sylvestris L. seeds, determined with the help of a hollow cylinder and a goniometer, is $32.7^{\circ}$. The significant discrepancy $\left(\sim 8^{\circ}\right)$ in the values obtained by these methods exceeds that described in [25], which can be explained by the shape of the particles of the bulk material. The flowability of Pinus sylvestris L. seeds corresponds to an excellent (free) [25,32] category.

The method of estimating the size of seeds of this size using a micrometer cannot be recommended for use, since it is extremely time-consuming, often leading to crushing of the seed during measurement.

The selected angle of inclination of the walls of the outlet hopper $\left(40^{\circ}\right)$ of the feeder corresponds to the accepted standards [27] in the design and the recommendations proposed [25], however, there is a phenomenon of self-formation, which indicates the need for further improvement of the proposed methods. 


\section{Discussion}

The static angle of the natural slope of Pinus sylvestris L. seeds was determined and the known data on the length and width of scots pine seeds were partially confirmed [33,34].

The known conclusion $[25,35]$ that the method of measuring the angle of natural slope affects the measured value of the angle of natural slope was confirmed.

For further experiments, it is planned to assemble a metal model of the hopper with four installed agitators, solder the control board for the piece-by-piece connection of the agitators.

In general, it can be argued that the problem of seeds-arch forming and gravitational outflow of Pinus sylvestris L. seeds for this feeder design is overcome, but in the future, it is necessary to study the following:

- The need to calibrate the seeds before serving.

- How does seed calibration affect the angle of natural slope?

- If calibration is affected, is there a need to create different feeders for different seed size categories?

\section{Conclusions}

The static angle of the natural slope in Pinus sylvestris L. seeds was determined by two methods. The recommended slope angle of hopper walls for storage of Pinus sylvestris L. seeds is $40^{\circ}$. Directions for further research on properties of Pinus sylvestris L. seeds as a bulk material were determined.

Author Contributions: Conceptualization, A.I.N.; methodology, I.V.B.; formal analysis, I.V.B. and A.I.N.; investigation, I.V.B. and A.I.N.; resources, I.V.B.; data curation, I.V.B. and E.P.P.; writingoriginal draft preparation, I.V.B., A.I.N., and E.P.P.; writing-review and editing, I.V.B., A.I.N., and E.P.P. All authors have read and agreed to the published version of the manuscript.

Funding: This research received no external funding.

Institutional Review Board Statement: Not applicable for studies not involving humans or animals. Informed Consent Statement: Not applicable for studies not involving humans.

Data Availability Statement: Pinus sylvestris L. seeds were used in this study. The cones were collected in the Lisinsky educational-and-experimental forestry farm (Leningrad region, Russia). The data presented in this study are openly available in Mendeley Data at doi:10.17632/9ygwcbkgrw.1, reference https:/ / data.mendeley.com/datasets/9ygwcbkgrw/1.

Acknowledgments: The authors acknowledge Anatoly V. Zhigunov, Saint Petersburg State Forest Technical University named after S.M. Kirov for valuable comments and the seeds provided for the study.

Conflicts of Interest: The authors declare no conflict of interest.

\section{References}

1. Stanturf, J.A.; Mansourian, S. Forest landscape restoration: State of play. R. Soc. Open Sci. 2020, 7, 201218. [CrossRef]

2. Ramantswana, M.; Guerra, S.P.S.; Ersson, B.T. Advances in the Mechanization of Regenerating Plantation Forests: A Review. Curr. For. Rep. 2020, 6, 143-158. [CrossRef]

3. Grossnickle, S.C.; Ivetić, V. Direct Seeding in Reforestation-A Field Performance Review. Reforesta 2017, 4, 94-142. [CrossRef]

4. Novikov, A.I.; Ersson, B.T. Aerial seeding of forests in Russia: A selected literature analysis. IOP Conf. Ser. Earth Environ. Sci. 2019, 226, 012051. [CrossRef]

5. Tigabu, M.; Daneshvar, A.; Jingjing, R.; Wu, P.; Ma, X.; Odén, P.C. Multivariate Discriminant Analysis of Single Seed Near Infrared Spectra for Sorting Dead-Filled and Viable Seeds of Three Pine Species: Does One Model Fit All Species? Forests 2019, 10, 469. [CrossRef]

6. Barboza da Silva, C.; de Bianchini, V.J.M.; de Medeiros, A.D.; de Moraes, M.H.D.; Marassi, A.G.; Tannús, A. A novel approach for Jatropha curcas seed health analysis based on multispectral and resonance imaging techniques. Ind. Crops Prod. 2021, 161, 113186. [CrossRef]

7. Novikov, A.I.; Lisitsyn, V.I.; Tigabu, M.; Tylek, P.; Chuchupal, S.V. Detection of Single Seed in Optoelectronic System of Mobile Grader: Mathematical Modeling. Forests 2020. under review. 
8. Novikov, A.I.; Drapalyuk, M.V.; Sokolov, S.V.; Ivetić, V. VIS-NIR wave spectrometric features of acorns (Quercus robur L.) for machine grading. IOP Conf. Ser. Earth Environ. Sci. 2019, 392, 012009. [CrossRef]

9. Novikov, A.I.; Sokolov, S.; Drapalyuk, M.; Zelikov, V.; Ivetić, V. Performance of Scots Pine Seedlings from Seeds Graded by Colour. Forests 2019, 10, 1064. [CrossRef]

10. Novikov, A.I. Visible wave spectrometric features of scots pine seeds: The basis for designing a rapid analyzer. IOP Conf. Ser. Earth Environ. Sci. 2019, 226, 012064. [CrossRef]

11. Novikov, A.I.; Saushkin, V.V. Infrared range spectroscopy: The study of the pine seed coat parameters. For. Eng. J. 2018, 8, 30-37. [CrossRef]

12. Sokolov, S.V.; Novikov, A.I. New optoelectronic systems for express analysis of seeds in forestry production. For. Eng. J. 2019, 9, 5-13. [CrossRef]

13. Albekov, A.U.; Drapalyuk, M.V.; Morkovina, S.S.; Vovchenko, N.G.; Novikov, A.I.; Sokolov, S.V.; Novikova, T.P. Device for Seeds Sorting. RU Patent 2682854, 21 March 2019.

14. Albekov, A.U.; Drapalyuk, M.V.; Morkovina, S.S.; Novikov, A.I.; Vovchenko, N.G.; Sokolov, S.V.; Novikova, T.P. Seed Sorting Device. RU Patent 2687509, 14 May 2019.

15. Drapalyuk, M.V.; Morkovina, S.S.; Novikov, A.I.; Vovchenko, N.G.; Sokolov, S.V.; Novikova, T.P. Seed Sorting Device. RU Patent 2700759, 14 September 2019.

16. Novikov, A.I.; Drapalyuk, M.; Dornyak, O.; Zelikov, V.; Ivetić, V. The Effect of Motion Time of a Scots Pine Single Seed on Mobile Optoelectronic Grader Efficiency: A Mathematical Patterning. Inventions 2019, 4, 55. [CrossRef]

17. Tylek, P.; Walczyk, J. Pneumatic single-seed drill for sowing beech nuts. Sylwan 2011, 155, 138-144. (In Poland)

18. Liu, W.; Hu, J.; Zhao, X.; Yao, M.; Lakhiar, I.A.; Zhao, J.; Liu, J.; Wang, W. An Adaptive Roller Speed Control Method Based on Monitoring Value of Real-Time Seed Flow Rate for Flute-Roller Type Seed-Metering Device. Sensors 2020, 21, 80. [CrossRef]

19. Morkovina, S.S.; Vovchenko, N.G.; Novikov, A.I.; Sokolov, S.V.; Dornyak, O.R. Seed Aerial Sowing Device. RU Patent 2712516, 21 May 2020.

20. Sokolov, S.V.; Novikov, A.I. Adaptive estimation of UVs navigation parameters by irregular inertial-satellite measurements. Int. J. Intell. Unmanned Syst. 2020, in press. [CrossRef]

21. Ivetić, V.; Devetaković, J.; Nonić, M.; Stanković, D.; Šijačić-Nikolić, M. Genetic diversity and forest reproductive material-from seed source selection to planting. iForest Biogeosci. For. 2016, 9, 801-812. [CrossRef]

22. Novikov, A.I.; Ersson, B.T.; Malyshev, V.V.; Petrishchev, E.P.; Ilunina, A.A. Mechanization of coniferous seeds grading in Russia: A selected literature analysis. IOP Conf. Ser. Earth Environ. Sci. 2020, 595, 012060. [CrossRef]

23. Tylek, P.; Demidov, D.N.; Lysych, M.N.; Petrishchev, E.P.; Maklakova, E.A. The features designed of mechatronic system of adaptive hopper's feeder: Case study for Scots pine seeds morphometry. IOP Conf. Ser. Earth Environ. Sci. 2020, $595,012054$. [CrossRef]

24. Bacherikov, I.; Lokshtanov, B. Determining the angle of repose of the bulk material. Izv. Sankt-Peterbg. Lesoteh. Akad. 2016, 214, 167-177.

25. Bacherikov, I.V. Improving the Operation of Enclosed Storages of Wood Bulk Materials; Saint Petersburg State Forest Technical University: Saint Petersburg, Russia, 2017.

26. Gyachev, L.V. Basic Theory of Hoppers and Silos; Altai Polytechnic Institute Press: Barnaul, Russia, 1986.

27. Guidelines for Determining the Characteristics of the Filling Material and Geometric Parameters of Hoppers; Stroiizdat: Moscow, Russia, 1978.

28. Bacherikov, I.; Lokshtanov, B. Kinds and Properties of the Milled Wood Intended for Bin Storage. Resour. Technol. 2017, 1, 18-44. [CrossRef]

29. Vinokurov, V.N.; Silaev, G.V.; Zolotarveskiy, A.A. Machines and Mechanisms for Forestry and Landscape Architecture; Vinokurov, V.N., Ed.; Academia Publishing Centre: Moscow, Russia, 2004; ISBN 5-7695-1452-3.

30. Subbotina, M.A.; Kolesnikova, T.G. Physico-mechanical characteristics of Siberian pine seeds. Bull. KSAU 2008, 6, 93-97.

31. Lukynenko, V.; Galych, I.; Domashich, K. Review of investigation of physico-mechanical properties of semans of forest crops. Bull. Petro Vasilenko Kharkiv Natl. Tech. Univ. Agric. 2017, 180, 85-88.

32. McGlinchey, D. Bulk Solids Handling; McGlinchey, D., Ed.; Blackwell Publishing Ltd.: Oxford, UK, 2008 ; ISBN 9781444305449.

33. Kaliniewicz, Z.; Tylek, P.; Markowski, P.; Anders, A.; Rawa, T.; Glazewska, E. Analysis of correlations between selected physical properties and color of Scots pine (Pinus sylvestris L.) seeds. Tech. Sci. 2014, 17, 259-274.

34. Sviridov, L.T. Sorting of Forest Seeds; VSUFT: Voronezh, Russia, 2002. (In Russian)

35. Beakawi Al-Hashemi, H.M.; Baghabra Al-Amoudi, O.S. A review on the angle of repose of granular materials. Powder Technol. 2018. [CrossRef] 